\title{
Analisis Peningkatan Faktor Keamanan Lereng Pada Areal Bekas Tambang Pasir Dan Batu di Desa Ngablak, Kecamatan Cluwak, Kabupaten Pati
}

\section{(The Analysis of Slope Safety Factors Improvemen at Sand and Gravel Post Mining Land Areas in Ngablak Village, Cluwak District, Pati Regency)}

\author{
Rinal Khaidar Ali ${ }^{1}$, Najib ${ }^{1}$, Ahmad Nasrudin ${ }^{1}$ \\ ${ }^{1}$ Departemen Teknik Geologi Fakultas Teknik Universitas Diponegoro
}

\begin{abstract}
Management of post mining land become serious concern for government in current time. Post mining area that located in Ngablak village, Cluwak districts of Pati is one of post mining areas that did not managed and creates problems to civilian and village government, for example are safety and environment problems. Safety of environment disturbed because of mining activities that finished and created unstable slope (potentially landslide) caused by land dredging. To solve this problems, government need to make some research about stability of slope and studies about method of analysis which can increase the safety factor of slope. Slope stability analysis can be done with Side 6.0 software which needs laboratory result data of soil mechanics. Methods that can increase slope's safety factor can be installation of retaining wall and cut and fill method that make the slope become terraces. Efficiency of method that will be selected, can be tested by using Slide 6.0 software. Installation of retaining wall could increase the safety factor's value become 1.103, this value represents that the slope is still potentially to be landslide. However, cut and fill can increases safety factor's value become 1.330, that representing slope condition is stable and safe.
\end{abstract}

Keywords: Post Land Mining, Pati, Slope Stability, Slope Safety Factor

\section{Pendahuluan}

Kegiatan penambangan di Indonesia, khususnya di Jawa Tengah, merupakan kegiatan yang dapat mendatangkan keuntungan ekonomis yang cukup menjanjikan. Hal ini yang menyebabkan kegiatan penambangan menjadi semakin marak akhir-akhir ini, khususnya pertambangan rakyat yang mementingkan hasil dan kurang memperhatikan faktor-faktor lingkungan. Di wilayah Propinsi Jawa Tengah mempunyai potensi bahan galian tambang yang tersebar di beberapa tempat. Keberadaan potensi tersebut memicu adanya kegiatan pertambangan yang di lakukan guna memenuhi kebutuhan manusia baik untuk kebutuhan pribadi maupun pembangunan berskala nasional.

Secara keseluruhan di Popinsi Jawa Tengah terdapat 74 IUP (ljin Usaha Pertambangan) dengan luas areal 5.859 ha, total volume bahan tambang tertambang mencapai 5.121.780 $\mathrm{m}^{3} /$ tahun dan menyerap tenaga kerja sebanyak 2.376 orang (Dinas ESDM Jawa Tengah, 2014). Tentu saja akan dampak dari kegiatan tersebut akan mengakibatkan dan menyisakan lahan bekas penambangan yang rusak serta berpotensi menimbulkan degradasi terhadap lingkungan.

* Korespodensi Penulis: (Rinal Khaidar Ali) Departemen Teknik Geologi Fakultas Teknik Universitas Diponegoro
Kerusakan lahan bekas tambang mempengaruhi kelestarian fungsi lingkungan, sehingga berdampak pada meningkatnya suhu lokal, terganggunya tatanan hidrologis, menurunnya fungsi tanah sebagai media tanam dan bencana (erosi, gerakan tanah, banjir lumpur), fenomena tersebut juga terkait dengan terjadinya penurunan aspek sosialekonomi penduduk. Adanya kerusakan lahan akibat aktivitas penambangan menyebar di hampir semua Kabupaten/Kota di Provinsi Jawa Tengah. Salah satu lokasi yang mengalami dampak negatif dari aktivitas penambangan yaitu di areal bekas aktivitas penambangan di Desa Ngablak Kecamatan Cluwak Kabupaten Pati.

\section{Tujuan Penelitian}

Terdapat beberapa tujuan dilakukannya penelitian ini, yaitu:

a). Mengetahui kondisi geologi dan persebaran litologi yang terdapat pada lokasi penelitian.

b). Mengetahui kondisi geologi teknik pada lokasi penelitian.

c). Mengetahui nilai faktor keamanan dan kestabilan lereng pada areal bekas tambang pada lokasi penelitian.

\section{Lokasi Penelitian}

Lokasi Penelitian merupakan areal bekas penambangan pasir dan batu yang berada di 
wilayah Desa Ngablak Kecamatan Cluwak Kabupaten Pati, (gambar 1)

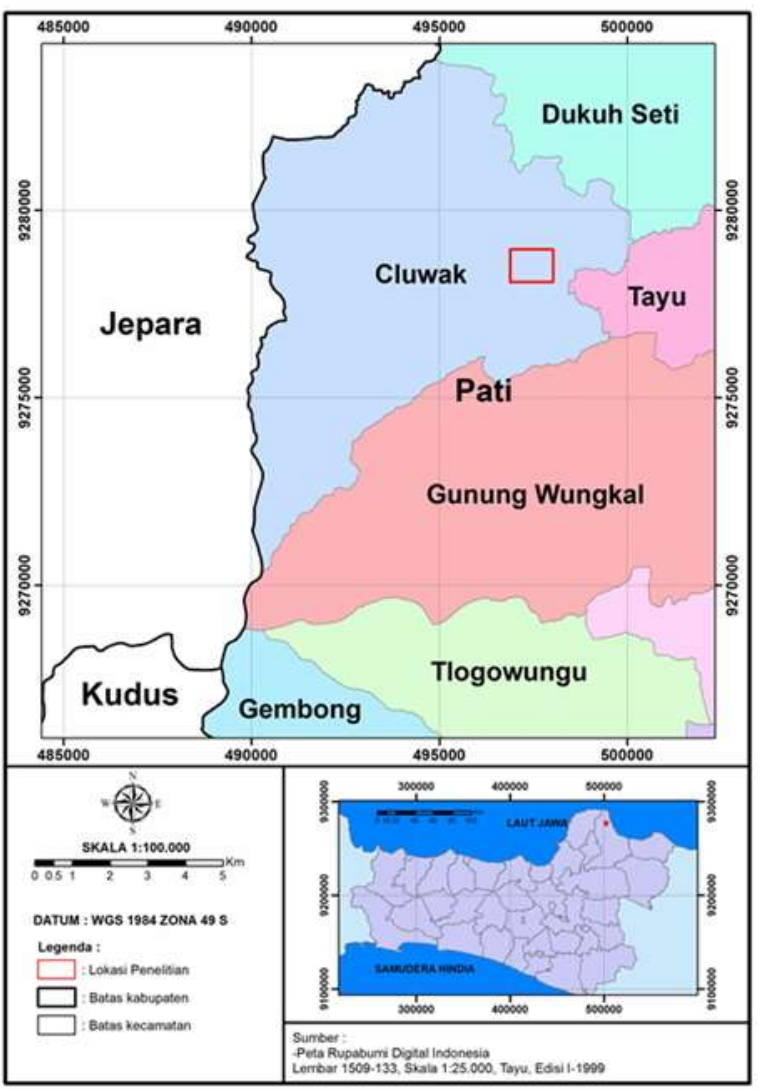

Gambar 1 Peta Administrasi lokasi penelitian

(Bappeda Kabupaten Pati,2012)

\section{Tinjauan Pustaka}

\section{Geologi Regional}

Berdasarkan peta Geologi Lembar Kudus skala 1:50.000, Kecamatan Cluwak merupakan endapan dari material erupsi Gunung Muria (Suwarti dan Wikarno, 1992). Desa Ngablak Kecamatan Cluwak secara regional terdiri dari satu satuan stratigrafi yaitu Tuff Muria (Qvtm), yang tersusun atas Tuff, Lahar dan Tuff pasiran. Penyebaran Tuff Muria ini meliputi seluruh wilayah Desa Ngablak dan bahkan sebagian besar Kecamatan Cluwak.

Menurut Sutarso dan Suyitno (1976), secara fisiografi daerah penelitian di Desa Ngablak termasuk dalam Zona Gunung Api Muria yang merupakan bagian dari endapan vulkanik di kaki Gunung Muria, (Van Bemmelen, 1949).

\section{Kondisi Tanah}

Dalam pengertian teknik secara umum, tanah didefinisikan sebagai material yang terdiri dari agregat (butiran) mineral-mineral padat yang tidak tersementasikan (terikat secara kimia) satu sama lain dari bahan-bahan organik yang telah melapuk (yang berpartikel padat) disertai dengan zat cair dan gas mengisi ruang-ruang kosong di antara partikel-partikel padat tersebut. Tanah berguna sebagai bahan bangunan pada berbagai macam pekerjaan teknik sipil, disamping itu tanah berfungsi juga sebagai pendukung pondasi dari bangunan (Das, 1994).

Sifat mekanis tanah merupakan sifat perilaku dari struktur massa tanah bila dikenai suatu gaya atau tekanan yang dijelaskan secara teknis mekanis (Kusuma, dkk, 2016). Untuk mengetahui sifat fisik tanah dapat dilakukan dengan cara pengamatan secara langsung, sedangkan untuk mengetahui mekanika tanah harus melalui uji laboratorium.

Beberapa aspek yang dihasilkan dalam uji laboratorium sifat mekanika tanah adalah sebagai berikut:

a. Kadar Air

Kadar air tanah ialah perbandingan berat air yang terkandung dalam tanah dengan berat kering tanah tersebut. Kadar air tanah dapat digunakan untuk menghitung parameter sifat - sifat tanah.

b. Berat Jenis Butir Tanah.

Menentukan berat jenis tanah ialah dengan mengukur berat sejumlah tanah yang isinya diketahui.

c. Batas Cair.

Batas cair tanah adalah kadar air minimum di mana sifat suatu tanah berubah dari keadaan cair menjadi plastis. Besaran batas cair digunakan untuk menentukan sifat dan klasifikasi tanah.

d. Batas Plastis.

Batas plastis (plastic limit/PL) adalah kadar air dimana suatu tanah berubah dari keadaan plastis keadaan semi solid. Batas Plastis dihitung berdasarkan persentasi berat air terhadap berat tanah kering pada benda uji.

e. Kuat Geser Tanah.

Kekuatan geser tanah adalah kekuatan tanah untuk melawan pergeseran yang terjadi di dalam tanah. Apabila tegangan normal tanah melampaui kuat geser tanah maka akan terjadi kelongsoran. Kuat geser tanah diperlukan untuk berbagai persoalan praktis terutama untuk menghitung daya dukung tanah, tegangan tanah terhadap dinding penahan tanah dan kestabilan lereng.

\section{Kestabilan Lereng}

Dalam menentukan kestabilan lereng, dikenal istilah Faktor Keamanan (Safety Factor), yang merupakan perbandingan antara gaya-gaya yang menahan, terhadap gaya-gaya yang menggerakkan tanah tersebut. Bila Faktor Keamanan lebih tinggi dari satu, umumnya lereng tersebut dianggap stabil. Kemantapan suatu lereng dinyatakan dengan "Faktor 
Keamanan (FK)", yang merupakan perbandingan antara besarnya gaya penahan dengan gaya penggerak longsoran.

\section{Faktor Keamanan Lereng Minimum}

Longsoran suatu lereng penambangan umumnya terjadi melalui suatu bidang tertentu yang disebut dengan bidang gelincir (slip surface).

kestabilan lereng tergantung pada gaya penggerak dan gaya penahan yang bekerja pada bidang gelincir tersebut. Gaya penahan (resisting force) adalah gaya yang menahan agar tidak terjadi longsoran, sedangkan gaya penggerak (driving force) adalah gaya yang menyebabkan terjadinya longsoran. Perbandingan antara gaya-gaya penahan terhadap gaya-gaya yang menggerakkan tanah inilah yang disebut dengan Faktor Keamanan (FK) lereng penambangan. Secara sistematis faktor keamanan suatu lereng dapat ditulis dengan rumus sebagai berikut: Dengan ketentuan, jika:

FK > 1,0: Lereng dalam kondisi stabil.

$\mathrm{FK}<1,0$ : Lereng tidak stabil.

$\mathrm{FK}=1,0$ : Lereng dalam kondisi kritis.

Mengingat banyaknya faktor yang mempengaruhi tingkat kestabilan lereng penambangan maka hasil analisa dengan $\mathrm{FK}=1,00$ belum dapat menjamin bahwa lereng tersebut dalam keadaan stabil. Hal ini disebabkan karena ada beberapa faktor yang perlu diperhitungkan dalam analisa faktor keamanan lereng penambangan seperti kekurangan dalam pengujian contoh di laboratorium, contoh batuan yang diambil belum mewakili keadaan sebenarnya di lapangan, tinggi muka air tanah pada lereng tersebut dsb.

Dengan demikian, diperlukan suatu nilai faktor keamanan minimum dengan suatu nilai tertentu yang disarankan sebagai batas faktor keamanan terendah yang masih aman sehingga lereng dapat dinyatakan stabil atau tidak. Sehingga pada penelitian ini, faktor keamanan minimum yang digunakan adalah $\mathrm{FK} \geq$ (sama dengan atau lebih besar) dari 1.25, sesuai prosedur dari (Bowles, 2000), Dengan ketentuan:

$\mathrm{FK} \geq 1,25$ : Lereng Aman.

$F K=1,07-1.25$ : Lereng Tidak Aman.

$\mathrm{FK}<1,07$ : Lereng kritis.

\section{Rocscience Slide}

Rocsience Slide adalah salah satu perangkat lunak geoteknik yang mempunyai spesialisasi sebagai software perhitungan kestabilan lereng.

Pada dasarnya Rocscience Slide adalah salah satu program di dalam paket perhitungan geoteknik Rocscience yang terdiri dari Swedge,
Roclab, Phase2, RocPlane, Unwedge, dan RocData.

Secara umum langkah analisis kestabilan lereng dengan Rocscience Slide adalah pemodelan, identifikasi metode dan parameter perhitungan, identifikasi material, penentuan bidang gelincir, running/kalkulasi, dan interpretasi nilai FoS dengan software komplemen Slide bernama Slide Interpret. Rocscience Slide banyak digunakan di industri khususnya pertambangan dan konstruksi khususnya tanggul, bendungan, dan lereng pada sisi jalan.

\section{Metode Penelitian}

Metode yang digunakan dalam penelitian ini adalah metode analisis kuantitatif dan kualitiatif. Alur metode penelitian secara lengkap dapat dilihat pada gambar 2. Tahap awal dimulai dengan dilakukannya studi literatur mengenai aspek-aspek yang dibutuhkan untuk mengetahui nilai faktor keamanan terhadap metode yang akan dilakukan untuk memperkuat tebing pada areal bekas tambang. Selanjutnya dilakukan studi tentang keadaan geologi regional daerah penelitian dan pengumpulan data sekunder yang dibutuhkan seperti:

1. Peta Rupabumi Indonesia.

2. Peta geologi regional daerah penelitian.

3. Peta administrasi daerah penelitian.

Untuk mendapatkan informasi awal mengenai daerah penelitian dalam melakukan survei dan penyelidikan lapangan. Tahap selanjutnya yang dilakukan yaitu penyelidikan lapangan untuk pengambilan data primer. Metode yang dilakukan yaitu pemetaan geologi teknik di wilayah Desa Ngablak serta uji sondir dan pengambilan undisturbed sample pada areal lahan bekas tambang. Pemetaan geologi teknik dilakukan dengan tujuan untuk mengetahui kondisi fisik batuan serta persebarannya pada lokasi penelitian. Pengambilan undisturbed sample bertujuan untuk mengetahui sifat mekanika tanah lokasi penelitian.

Setelah dilakukan penyelidikan lapangan serta uji laboratorium mekanika tanah dari undisturbed sample, maka didapatkan data geologi teknik, data hasil uji sondir dan data mekanika tanah. Tahap selanjutnya yaitu mengolah dan menginterpretasi data-data tersebut dengan menggunakan perangkat lunak Slide 6.0. Data geologi fisik diolah dan diinterpretasi sehingga mendapatkan hasil peta geologi teknik. Dari semua aspek data-data yang diperoleh dapat di interpretasikan dan didapatkan perencanaan yang tepat untuk penanggulangan lereng. 


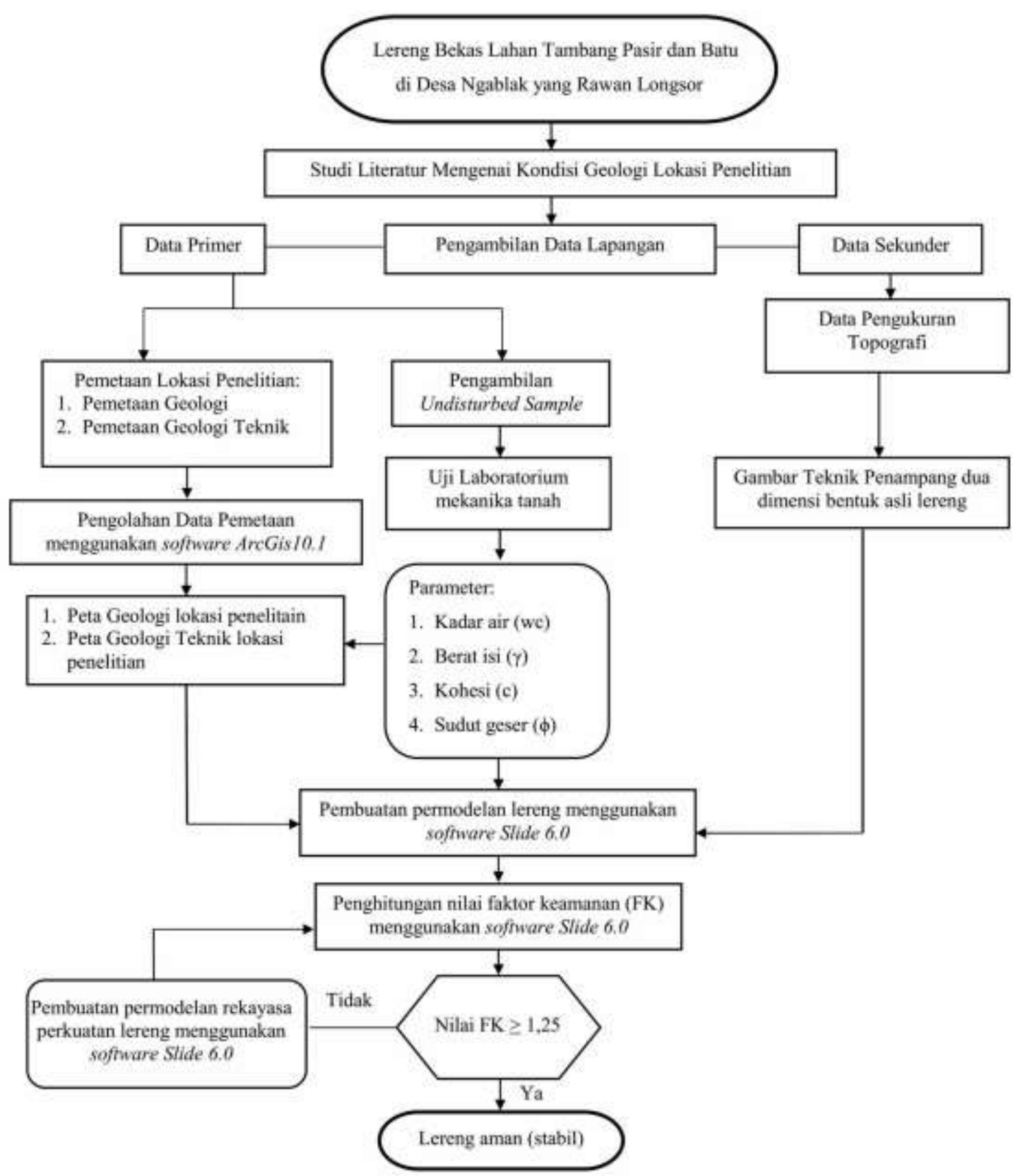

Gambar 2. Diagram Alir Penelitian

\section{Hasil dan Pembahasan}

\section{Litologi Penyusun Daerah Penelitian}

Desa Ngablak, Kecamatan Cluwak berada di bagian utara Kabupaten Pati, di sisi timur laut Gunung Muria. Pada lokasi ini ditemukan dua jenis litologi yang berbeda, yaitu Satuan Breksi dan Satuan Tuff (gambar 3). 


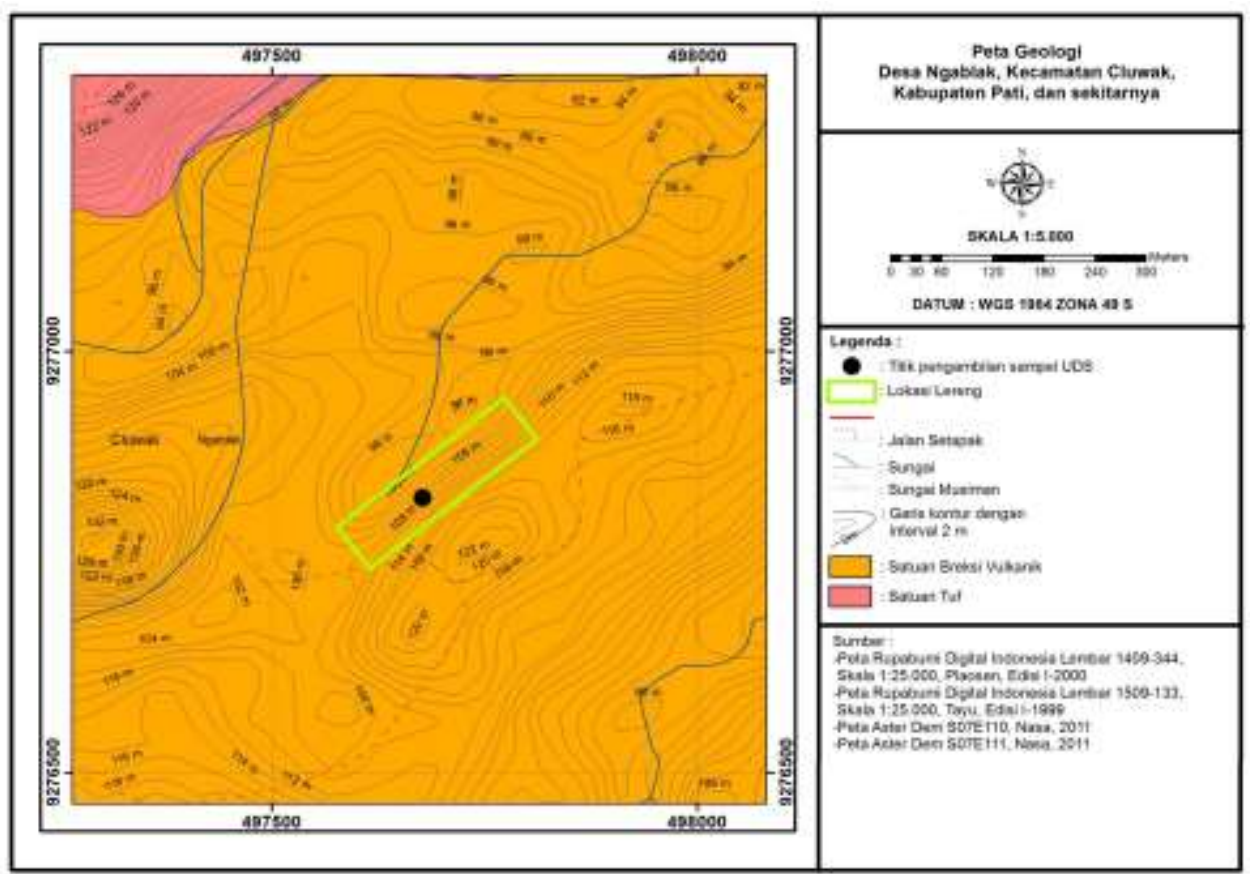

Gambar 3. Peta Geologi Daerah Penelitian

\section{Satuan Breksi Vulkanik}

Sekitar $85 \%$ area pada lokasi penelitian tersusun oleh litologi Satuan Breksi Vulkanik (gambar 4). Satuan Breksi ini mempunyai warna coklat, berstruktur masif, masih terlihat sortasi yang buruk dan tersusun atas fragmen berupa andesit berukuran kerakal (4-64 $\mathrm{mm})$ - bongkah $(>64 \mathrm{~mm})$ dan matriks berupa tuff berukuran pasir sedang (1/4-1/2 mm) sampai pasir kasar $(1 / 2-1 \mathrm{~mm})$.

\section{Satuan Tuff}

Litologi tuff (gambar 4) berwarna putih kecoklat coklatan, berstruktur masif, tersortasi baik, kemas tertutup dengan sortasi baik dan berukuran pasir sedang (1/4-1/2 mm) sampai pasir kasar $(1 / 2-1 \mathrm{~mm})$, memiliki arah perlapisan (dip/strike) N65[E/15凸 tersebar di bagian utara lokasi penelitian dan melampar sekitar $15 \%$ dari total pelamparan Desa Cluwak.

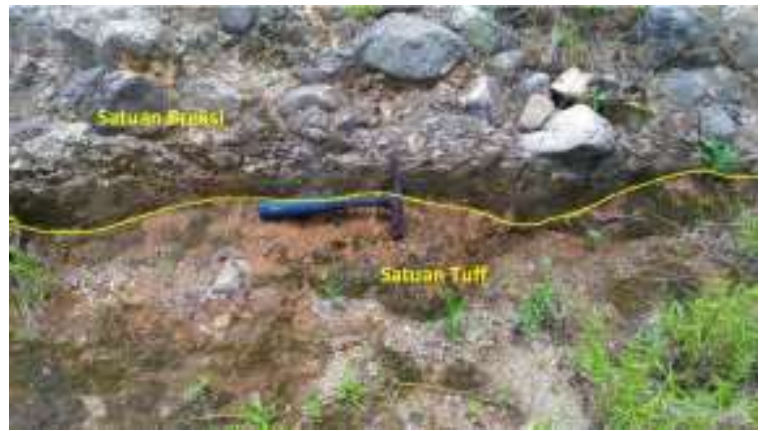

Gambar 4. Kenampakan Singkapan Breksi dan Tuff di Lapangan

\section{Kondisi Geologi Teknik Daerah Penelitian}

Untuk mengetahui kondisi geologi teknik pada lokasi penelitian, maka dilakukan pemetaan geologi teknik. Pemetaan geologi teknik mengacu pada sifat fisik batuan. Berbeda dengan pemetaan geologi yang mengacu pada jenis batuan dasar sehingga kurang begitu memperhatikan perbedaan fisik batuan. Dari hasil pemetaan geologi tenknik, maka didapatkan 1 (satu) satuan geologi teknik, yaitu Satuan Material Lepas Berukuran Berukuran Pasir $(1 / 16-$ $2 \mathrm{~mm}$ ) - Bongkah (> $64 \mathrm{~cm}$ ) (Gambar 5). 


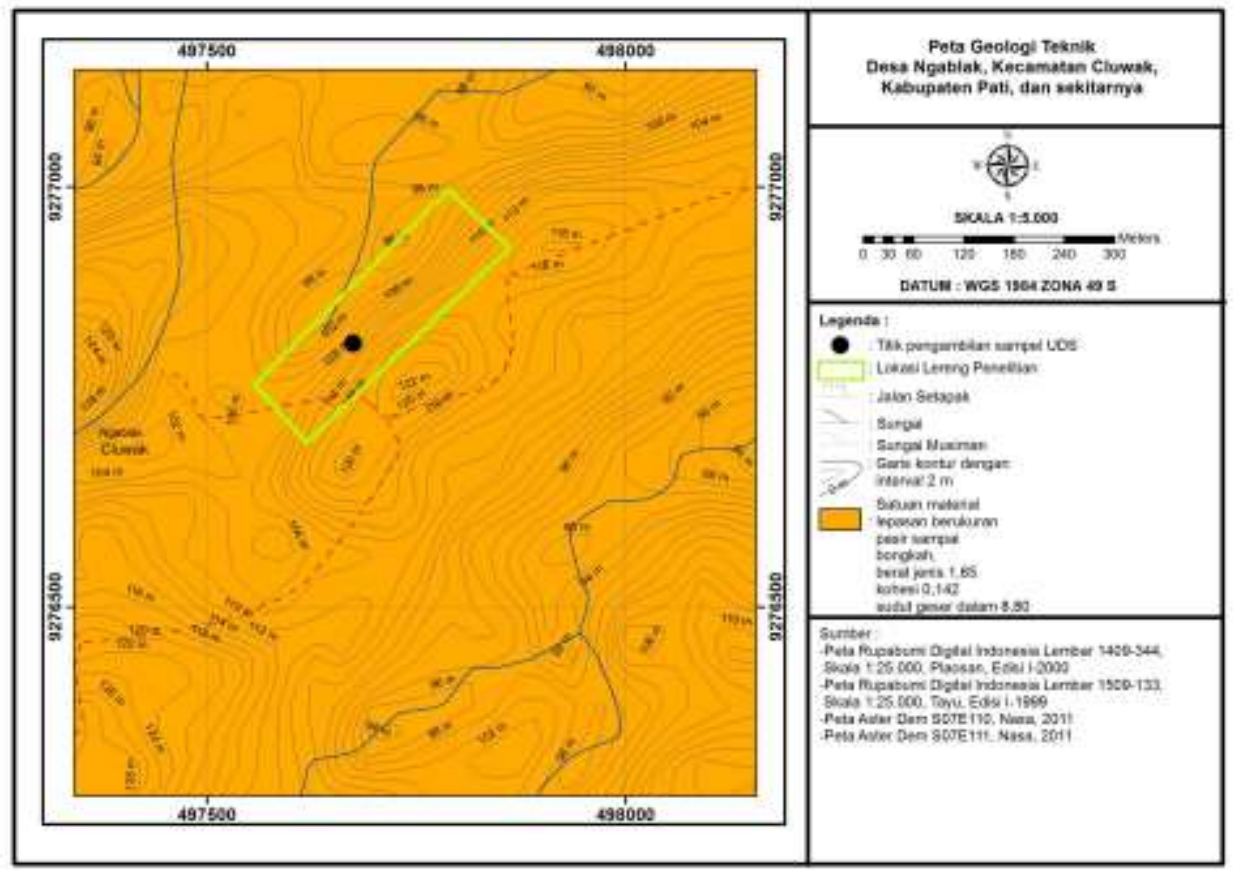

Gambar 5. Peta Geologi Teknik Daerah Penelitian

Satuan Material ini merupakan hasil rombakan/pelapukan dari satuan breksi dan juga hasil dari endapan sungai yang belum terkompaksi. Satuan material ini bewarna abu abu kecoklatan, berukuran pasir - bongkah serta masih bersifat lepasan (gambar 6). Berdasarkan hasil analisis uji laboratoirum atas undistrbed sample, sifat mekanika tanah di satuan ini yaitu mempunyai kandungan air $51,79 \%$, berat isi kering $1,09 \mathrm{gr} / \mathrm{cm}^{3}$, jenuh air $1,65 \mathrm{gr} / \mathrm{cm}^{3}$, kohesi $0,142 \mathrm{~kg} / \mathrm{cm}^{2}$ dan sudut geser dalam $(\phi)$ sebesar $8,80^{\circ}$ (tabel 1).

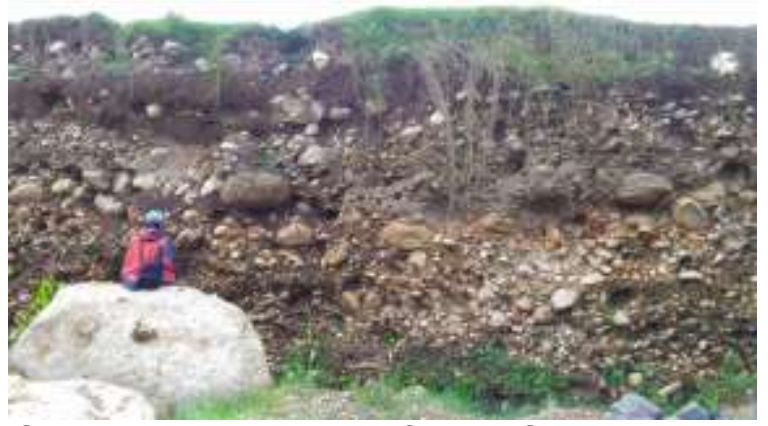

Gambar 6. Kenampakan Satuan Geologi Teknik Pasir-Bongkah di Lapangan

Tabel 1. Data Hasil Uji Laboratorium Mekanika Tanah dari Undisturbed Sample

\begin{tabular}{|c|c|c|c|c|c|c|c|}
\hline \multirow{3}{*}{$\begin{array}{l}\text { Depth } \\
\text { (m) }\end{array}$} & \multirow{3}{*}{ Description } & \multirow{2}{*}{$\begin{array}{l}\text { Water } \\
\text { Content }\end{array}$} & \multicolumn{3}{|c|}{ Unit Weight } & \multicolumn{2}{|c|}{ Direct Shear } \\
\hline & & & Wet & yDry & үSat & c & $\phi$ \\
\hline & & (\%) & griam ${ }^{3}$ & $\mathrm{gr} / \mathrm{cm}^{3}$ & $\mathrm{gr} / \mathrm{cm}^{3}$ & $\mathrm{~kg} / \mathrm{cm}^{2}$ & degree \\
\hline $\begin{array}{l}0- \\
0.50\end{array}$ & $\begin{array}{c}\text { Pasir } \\
\text { Kelempungan } \\
\text { Coldlat. Lunak }\end{array}$ & 51.79 & 1.65 & 1.09 & 1.67 & 0.142 & 8.80 \\
\hline
\end{tabular}

Analisis Faktor Keamanan Kestabilan Lereng Menggunakan Perangkat Lunak Slide 6.0
Perangkat lunak Slide 6.0 membutuhkan beberapa parameter data untuk dapat melakukan analisis kestabilan lereng/tebing. Beberapa parameter yang dibutuhkan antara lain bentuk dua dimensi lereng, sifat material lereng (material properties) dengan parameter berupa berat isi material dalam keadaan basah ( $\gamma$ Wet), kohesi (c), dan derajat sudut geser dalam $(\phi)$.

Perangkat lunak Slide 6.0 menyediakan beberapa pilihan metode untuk mengolah datadata yang telah dimasukkan untuk analisis dan perhitungan nilai faktor keamanan lereng. Metode - metode yang tersedia dalam perangkat lunak Slide 6.0 ini diantaranya yaitu metode Bishop, metode Corps of Engineers, metode Mongestern-Price, metode Janbu, metode LoweKarafiath, metode Fellenius (Ordinary), dan metode Spencer.

Berdasarkan penelitian-penelitian yang telah dilakukan dan studi-studi yang menyeluruh tentang keruntuhan lereng, maka dibagi 3 kelompok rentang Faktor Keamanan (FK) ditinjau dari intensitas kelongsorannya (Bowles, 1989), seperti yang diperlihatkan pada tabel 2 .

Tabel 2. Hubungan Nilai Faktor Keamanan dan Intensitas Longsor (Bowles, 1989)

\begin{tabular}{ll}
\hline Nilai Faktor Keamanan & Kejadian / Intensitas Longsor \\
\hline FK kurang dari 1,07 & Longsor sering terjadi (lereng labil) \\
FK antara 1,07 sampai 1,25 & Longsor pernah terjadi (lereng knitis) \\
FK lebih dari 1,25 & Longsor jarang terjadi (lereng relatif stabil) \\
\multicolumn{1}{c}{ Perhitungan } & yang pertama kali dilakukan
\end{tabular}

Perhitungan yang pertama kali dilakukan adalah perhitungan untuk mengetahui besaran nilai faktor keamanan lereng pada kondisi awal. Kondisi awal lereng mempunyai dimensi yaitu tinggi lereng 6,78 meter dengan sudut kemiringan lereng $46,7^{\circ}$. Material penyusun 
lereng ini mempunyai sifat keteknikan berupa nilai unit weight sebesar $16,5 \mathrm{kN} / \mathrm{m}^{3}$, nilai kohesi sebesar $14,2 \mathrm{kN} / \mathrm{m}^{2}$, dan nilai sudut geser dalam $(\phi)$ sebesar $8,80^{\circ}$. Dari data - data ini kemudian dilakukan perhitungan secara otomatis menggunakan perangkat lunak Slide 6.0 dengan metode perhitungan Fellenius (Ordinary) dan metode Bishop. Hasil perhitungan menunjukkan nilai FK lereng pada kondisi awal sebesar 0,990 (gambar 7).

Berdasarkan klasifikasi Bowles, 1989 (tabel 2) dengan nilai FK lereng sebesar 0,990 (FK kurang dari 1,07) maka lereng ini masuk dalam kategori lereng labil atau lereng yang berpotensi sering terjadi longsor. Hal ini menyebabkan kawasan sekitar lereng menjadi tempat yang tidak aman bagi warga sekitar yang ingin melakukan aktivitas.

Tindakan yang perlu dilakukan untuk meningkatkan keamanan dan kestabilan lereng yaitu dengan cara melakukan metode perkuatan lereng. Ada beberapa metode perkuatan lereng yang dapat dilakukan, diantaranya yang akan dipakai dalam analisis ini adalah metode pemasangan dinding penahan dan metode terasering atau metode cut and fill.

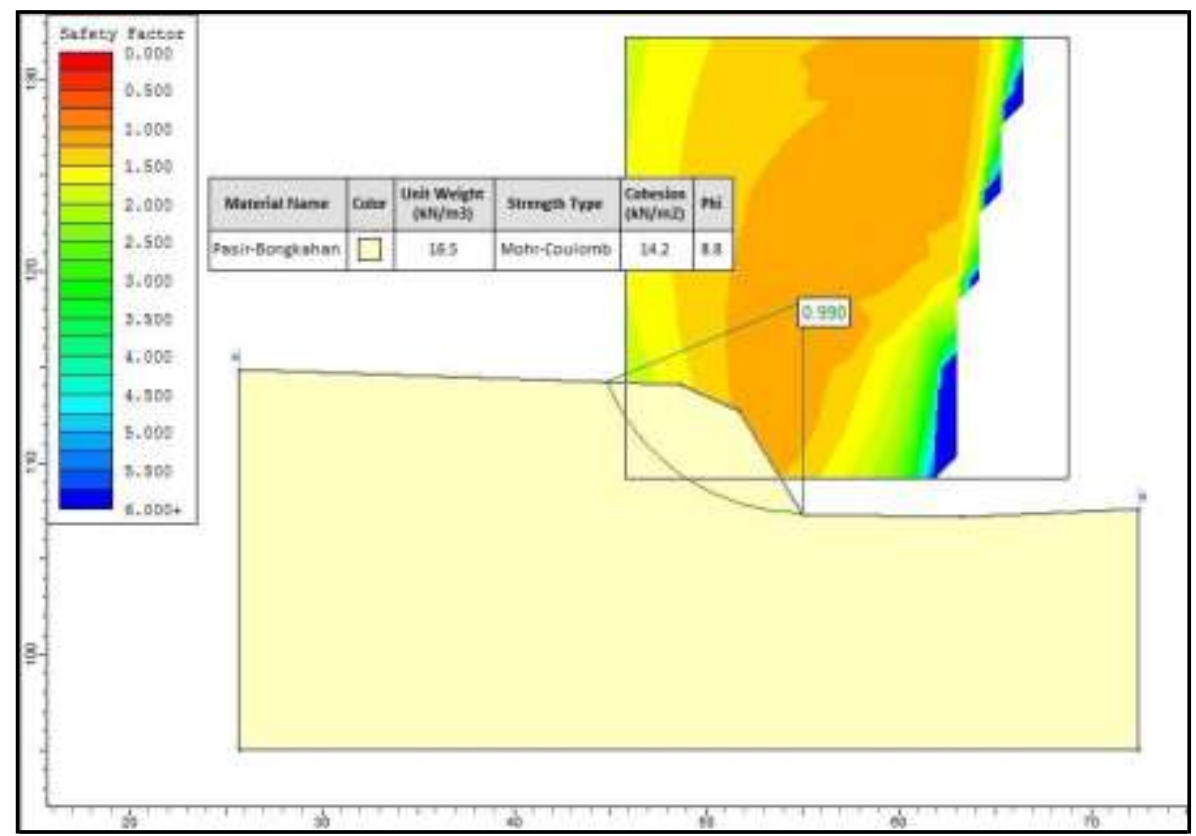

Gambar 7. Permodelan Bentuk Awal Lereng Dengan Nilai Faktor Keamanan Hasil Perhitungan Menggunakan Software Slide 6.0

Metode Perkuatan Lereng Dengan Dinding Penahan Tanah

Dinding penahan tanah adalah suatu konstruksi yang berfungsi untuk menahan dan mencegah keruntuhan/kelongsoran tanah yang miring atau lereng yang kemantapannya tidak dapat dijamin oleh lereng tanah itu sendiri. Tanah yang tertahan memberikan dorongan secara aktif pada struktur dinding sehingga struktur cenderung akan terguling atau akan tergeser.

Ketentuan dalam pembuatan pembuatan dinding penahan tanah didasarkan pada SNI 2847:2013 khususnya dalam bab 14 tentang dinding struktural. Dimensi dinding penahan yang akan dibangun setinggi 5,4 meter dengan ketebalan 0,5 meter pada bagian atas bangunan dinding penahan dan menebal ke bawah sampai pada bagian dasar dinding pada permukaan tanah setebal 1 meter. Kemiringan bangunan dinding penahan sama seperti kemiringan lereng karena dinding penahan dibangun menempel pada lereng. Material Properties dari dinding penahan tanah pada permodelan mempunyai nilai yWet sebesar $20 \mathrm{kN} / \mathrm{m}^{2}$, c sebesar $50 \mathrm{kN} / \mathrm{m}^{2}$ dan nilai sudut geser dalam $(\phi)$ sebesar $35^{\circ}$. (Badan Standardisasi Nasional, 2013).

Hasil analisis dan perhitungan pada permodelan lereng yang telah dilakukan perkuatan dengan pemasangan konstruksi dinding penahan tanah menunjukkan peningkatan nilai faktor keamanan tebing. Nilai FK yang dihasilkan dari metode perkuatan lereng dinding penahan ini adalah 1,103 (gambar 8).

Berdasarkan klasifikasi Bowles, 1989 (Tabel 2) dengan nilai FK lereng sebesar 1,103 (FK antara 1,07 sampai 1,25$)$ maka lereng ini masuk dalam kategori lereng kritis atau lereng yang pernah terjadi longsor dan masih berpotensi terjadi longsor kembali. 


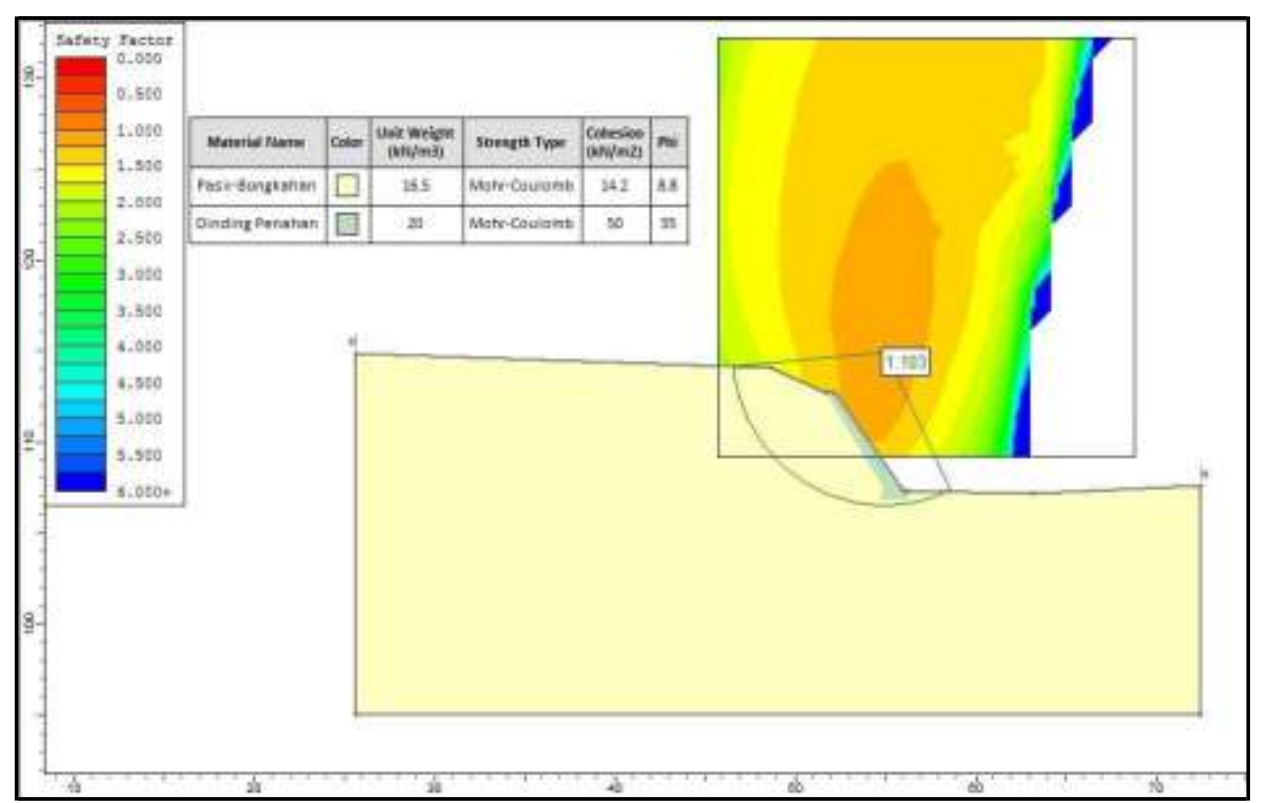

Gambar 8. Hasil Perhitungan Faktor Keamanan Pada Lokasi Penelitian Dengan Metode Perkuatan Lereng Dinding Penahan Tanah Menggunakan Software Slide 6.0

\section{Metode Perkuatan Lereng Dengan Terasering atau Cut and fill}

Prinsip dasar dari metode cut and fill ini yaitu menggali atau memotong (cut) dan menimbun urugan atau mengisi (fill). Maksud dari metode ini yaitu menggali atau memotong bagian lereng yang lebih tinggi kemudian tanah hasil galian tersebut digunakan sebagai tanah urugan bagian bawah lereng. Inti dari metode cut and fill ini adalah merubah geometri lereng, baik slope atau sudut kemiringan lereng, ketinggian lereng, dan merubah bentuk lereng menjadi berundak.

Untuk menguji efisiensi dari metode cut and fill ini, maka perlu dilakukan perhitungan dan analisis nilai faktor kemanan lereng. Analisis dan perhitungan nilai faktor keamanan lereng menggunakan pembuatan permodelan dengan perangkat lunak Slide 6.0. Permodelan kondisi awal lereng yang telah dibuat dapat digunakan untuk membantu dalam analisis ini, dari permodelan tersebut kemudian dilakukan potongan - potongan pada bagian dimensi lereng sesuai dengan desain cut and fill dari gambar teknik.

Dimensi awal lereng mempunyai ukuran tinggi 6,78 meter dengan sudut kemiringan lereng $46,7^{\circ}$. Selanjutnya dilakukan perkuatan cut and fill dengan merubah bentuk lereng menjadi dua undakan/jenjang dengan slope yang lebih landai dibandingkan keadaan awal lereng. Jenjang lereng bagian bawah menjadi setinggi 3,6 meter dengan sudut kemiringan lereng $39,9^{\circ}$ dan tinggi jenjang lereng bagian atas menjadi 3,9 meter dengan sudut kemiringan lereng sebesar $43,6^{\circ}$.

Setelah dilakukan analisis dan perhitungan nilai FK dengan metode Fellenius dan Bishop menggunakan perangkat lunak Slide 6.0 pada kondisi lereng dengan perkuatan cut and fill, didapatkan hasil berupa peningkatan nilai FK yang cukup signifikan. Nilai faktor keamanan pada kondisi awal tebing sebesar 0,990 dan setelah dilakukan perkuatan dengan metode cut and fill didapatkan nilai faktor keamanan sebesar 1,332 (Gambar 9).

pemasangan dinding penahan dan metode terasering atau metode cut and fill. 


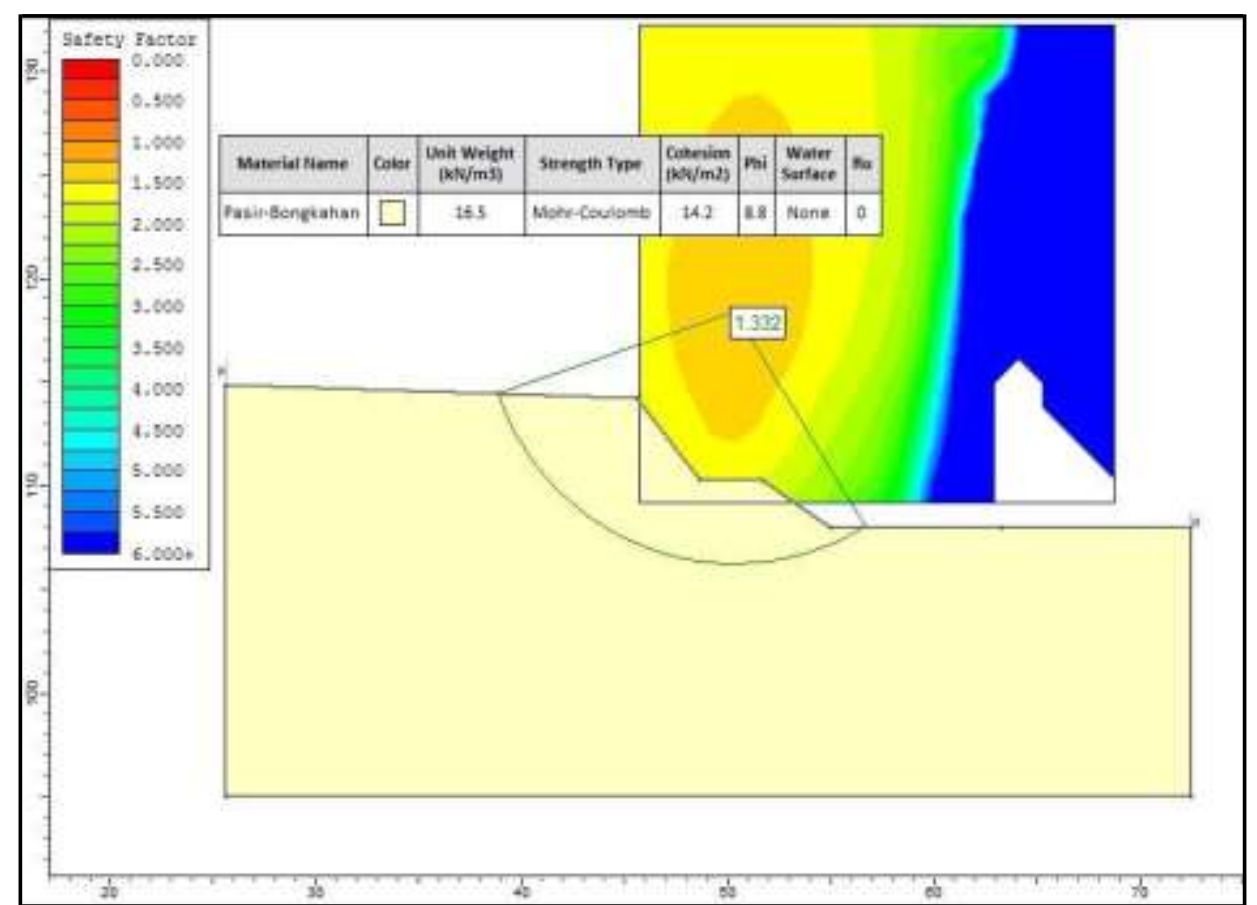

Gambar 9. Hasil Perhitungan Faktor Keamanan Pada Lokasi Penelitian Dengan Metode Perkuatan Lereng Metode Terasering/Cut and fill Menggunakan Software Slide 6.0

Berdasarkan klasifikasi Bowles, 1989 dengan nilai FK lereng yang dihasilkan sebesar 1,332 (FK di atas 1,25) maka dapat diinterpretasikan bahwa setelah dilakukan perkuatan lereng dengan metode cut and fill, lereng dalam kondisi yang aman dan relatif stabil dan jarang terjadi longsor dengan potensi longsor yang sangat kecil.

Analisis kestabilan lereng dan perhitungan nilai FK yang telah dilakukan menggunakan perangkat lunak Slide 6.0, menunjukkan bahwa kondisi lereng yang berbeda dengan sifat material penyusun lereng yang sama akan menghasilkan kestabilan lereng yang berbeda. Hasil analisis kestabilan lereng yang menunjukkan keterkaitan kondisi lereng, nilai faktor keamanan dan tingkat kestabilan lereng akan ditunjukkan Tabel 3.

Tabel 3 Hasil Perhitungan Nilai Faktor

Keamanan Dan Analisis Kestabilan Lereng

\begin{tabular}{lcl}
\hline Kondisi Lereng & $\begin{array}{l}\text { Nilai FK yang } \\
\text { dihasilkan }\end{array}$ & $\begin{array}{l}\text { Keamanan dan Kestabilan } \\
\text { Lereng }\end{array}$ \\
\hline Lereng awal & 0,990 & $\begin{array}{l}\text { Lereng labil (berpotensi sering } \\
\text { terjadi longsor) }\end{array}$ \\
Lereng dengan konstruksi & 1,103 & $\begin{array}{l}\text { Lereng kitis (potensi longsor } \\
\text { kecil) } \\
\text { dinding penahan }\end{array}$ \\
Lereng hasil cut and fil & 1,330 & Lereng stabil \\
\hline
\end{tabular}

\section{Kesimpulan}

Berdasarkan hasil penelitian yang telah dilakukan didapatkan kesimpulan sebagai berikut:

1. Daerah penelitian berada di Desa Ngablak Kecamatan Cluwak Kabupaten Pati terdiri dari litologi berupa Satuan Breksi Vulkanik dan Satuan Tuff.
2. Pada daerah penelitian terdapat 1 (satu) satuan geologi teknik, yaitu Satuan Material Lepas Berukuran Berukuran Pasir $(1 / 16-2$ $\mathrm{mm})$ - Bongkah (> $64 \mathrm{~cm})$

3. Nilai faktor keamanan lereng pada kondisi awal sebesar 0,990, lereng dengan pembuatan dinding penahan tanah meningkatkan nilai faktor keamanan menjadi 1,103 dan metode cut and fill yang dapat meningkatkan faktor keamanan tanah menjadi 1,330 .

\section{Daftar Pustaka}

Badan Standardisasi Nasional. (2013) Persyaratan Beton Struktural Untuk Bangunan Gedung. Jakarta: BSN

Bappeda Kabupaten Pati. (2012) Pengenalan Wilayah Dan Potensi Kabupaten Pati. Pati: Bappeda.

Bishop, A.W. (1955) The Use of the Slip Circle in the Stability Analysis of Slopes.Great Britain: Geotechnique Vol. 5, No. 1, Mar., pp. 7-17.

Bowles, J.E. (1989) Sifat-sifat Fisik \& Geoteknis Tanah, Jakarta: Erlangga.

Buma, J. \& Van Asch, T. (1997) Landslide Recognition. Chicester: Wiley.

Das, B.M. (1994) Mekanika Tanah Jilid 1 (PrinsipPrinsip Rekayasa Geoteknik). Jakarta: Erlangga.

Dinas ESDM Jateng. (2014) Rekap Daftar Izin Usaha Pertambangan (IUP) Operasi Produksi. Semarang: Dinas ESDM.

Hardiyatmo, H.C. (1992) Mekanika Tanah I, Jakarta: PT. Gramedia Pustaka Utama. 
Karnawati, Dwikorita. (2005) Bencana Alam Gerakan Massa Tanah di Indonesia dan Upaya Penanggulangannya. Yogyakarta: Jurusan Teknik Geologi Universitas Gadjah Mada

Kusuma, R.I., Mina, E., \& Ihsan, I. (2016) Tinjauan Sifat Fisis dan Mekanis Tanah. Jurnal Fondasi Volume 5 No. 2

Maulana, H. \& Inayatillah, A. (2013) Analisis Kestabilan Lereng dengan Software Sockscience Slide 6.0 \#1. Jakarta: Civil for Future.

Pangemanan, Violetta G.M. 2014. Analisis Kestabilan Lereng dengan Metode Fellenius. Juranal Sipil Statik Volume 2 No.1 hal 37-46.
Sutarso, B. \& Suyitno, P. (1976) The Diapiric Structure and its relations to the occurrence of hydrocarbon in Northeast Java Basin. Presentasi Paper Pertemuan Ke 5 IAGI. 46 Halaman.

Suwarti, T. dan Wikarno, R. (1992) Peta Geologi Lembar Kudus, Jawa. Bandung: Puslitbang Geologi.

Van Bemmelen, R.W. (1949) The Geology of Indonesia. Martinus Nyhof: The Haque.

Varnes, D.J. (1978) Slope Movement Types nad Processes. Washington D. C: Transportation and Road Research Board, National Academy of Science. 